\title{
Feasibility of Single-Storey Brickwork Columns for House Construction
}

\author{
S. R. De S. Chandrakeerthy
}

\begin{abstract}
In Sri Lanka, reinforced concrete columns are widely used as isolated columns in single-storey houses and single-storey segments of two-storey houses, primarily to accommodate architectural features, which require large openings. As loads sustained by such columns are moderate and the reinforced concrete columns traditionally used for them are over-designed due to restrictions imposed by the concrete design code on slenderness, durability, column reinforcement area and locations, as well as shear link area and spacing. Thus a study on structural and economic feasibility of alternative solutions made of unreinforced and reinforced brickwork were considered opportune.
\end{abstract}

The investigation comprised of a literature survey and a design study. The design study considered thirty typical house plans used in Sri Lanka. It also considered three foundation conditions: poor soil (clay), average soil (sand) and good soil (laterite). Thirty-nine column locations were identified in those plans, and designs were done in reinforced concrete, reinforced brickwork and unreinforced brickwork to cover the above three soil conditions. The design and costing was computerized using EXCEL so that by replicating designs with changed section properties, each solution can be optimized at minimum cost. The study generated 351 different column solutions.

The study concluded that unreinforced and reinforced brickwork columns are an economical solution to replace single-storey reinforced concrete columnis in the above type of house construction. However, bulkier unreinforced brickwork columns are unlikely to be popular.

Keywords: Brickwork, Concrete, Single-storey columns

\section{Introduction}

Brickwork is the most widely used structural material for single-storey and two-storey house construction in Sri Lanka. Although brickwork columns also had a long tradition of success, current trend is to use reinforced concrete in situations where a column is needed due to either incorporation of large open areas in the house plan or specification of large openings in walls. Popularity of concrete design and construction among Structural Engineers, reluctance to treat local brickwork as a structural material, and placement of a lower preference for cost savings and a greater importance for reduction of column size, may have contributed to this new trend.

Since lately, many Structural Engineers are rethinking on the feasibility of using reinforced concrete for single-storey columns to carry roof and ceiling loads of houses. Due to lower loads on them, single-storey reinforced concrete columns are over-designed [1] due to restrictions on concrete grade to provide durability to reinforcements, restrictions on sectional area due to slenderness considerations, and restrictions on reinforcement and shear link areas as well as their spacing to control cracking. The viability of low load carrying column options such as the popular pre-cast singlestorey column with constrictions of narrow area and incorporation of ancient architectural features, where their normal designs fall outside the BS 8110 specifications [1], confirms the above view. Hence, brickwork and reinforced brickwork columns are likely to provide economical options to replace reinforced concrete single-storey columns to carry roof and ceiling loads.

Viability of brickwork or reinforced brickwork, for single-storey columns carrying roof and ceiling loads of houses is supported by the following considerations: (a) A brickwork column will entirely eliminate reinforcements and concrete to reduce cost, while reinforced brickwork column will reduce reinforcement,

Bng. Prof. S.R.De S Chandrakeerthy - B.Se.Eng.(Hons)Cey.. Ph.D(ShefJeld), C.Eng.. FIE(S.L) is a Senior Prefessur of Civll Engineering at Unlversily of Moratuwe. 
links and concrete costs; (b) A brickwork or reinforced brickwork will be economical as they are easy to build requiring no formwork; (c) Brickwork as reinforced brickwork columns, which are generally larger, may reduce pad footing cost by reducing cantilevered pad footing area, thereby economizing on both pad concrete and reinforcements; (d) Reinforced brickwork columns can manage with comparatively smaller diameter mild steel reinforcements; (e) ) Use of small vertical lifts whose height is the lesser of: $300 \mathrm{~mm}$ or 6 times the width of grout space, enables better compaction and better supervision; ( $f$ ) Reinforced brickwork provides greater protection to reinforcements than the protection in a reinforced concrete column of identical concrete cover, as surrounding brickwork just outside the concrete cover will compete successfully for moisture present in the vicinity of reinforcement due to greater porosity of brickwork; and $(\mathrm{g})$ Brickwork and reinforced brickwork are labour intensive techniques, with the mason as a key player using less expensive technology, which suits most Sri Lankan conditions better.

Further, as many local Structural Engineers are reluctant to design in brickwork and reinforced brickwork, unless research demonstrates their potential and viability, it will remain as unexplored territory, depriving their benefits to many potential future users. This investigation is directed to provide answers to the above concerns.

\section{The Investigation}

The investigation consists of a literature survey and a design study [2].

The literature survey [ 1 to 19$]$ focussed on brickwork and reinforced brickwork columns with greater emphasis on reinforced brickwork. The areas covered were: Common brickwork and reinforced brickwork column arrangements, reinforcement and shear link arrangements for reinforced brickwork columns, design and construction process of reinforced brickwork, properties of local bricks, and durability of reinforced brickwork with local bricks.

The design study considered three conservative foundation conditions defined as good soil (or laterite), average soil (or sand), and poor soil (or clay), where the allowable bearing pressures were assumed to be 200,125 and $50 \mathrm{kN} / \mathrm{m} 2$ respectively [16,17]. Thirty Architect designed, house plans were considered. For each different column location in those house plans, designs were done in brickwork, reinforced brickwork and reinforced concrete to cover the above three soil conditions. This enabled the design study to capture a large range of single-storey columns carrying roof and ceiling loads with various combinations of eccentricities and design loads.

The design process of reinforced brickwork columns [2 to 19] consists of applying ultimate limit state philosophy similar to reinforced concrete design. To ensure durability, low strength bricks require [12] Grade 20 concrete pockets to surround reinforcements. These pockets have significant strength in comparison to brickwork, and hence theories applicable for high strength bricks should be suitably amended to account for these comparatively strong concrete pockets. The design and costing processes were computerized using EXCEL to enable performance of repetitive designs to attain structural optimization at minimum cost. Computerized Building Schedule of Rates [13] was used in costing with material and labour rates effective in December 2005. To customize the rates to reinforced brickwork, which is not much used in Sri Lanka, following modifications were incorporated: (a) When 1:2:4 $(14 \mathrm{~mm})$ concrete was used, 1:2:4 $(20 \mathrm{~mm})$ rates were changed by increasing material volume by $20 \%$ to account for wastage, labour rate by $100 \%$ for extra work and inserting the actual market price of $14 \mathrm{~mm}$ aggregate; (b) When 1 cement: 8 sand mortar is used, 1 cement: 6 sand rates were changed accordingly to obtain new volumes of the constituent materials; and (c) Brickwork material volumes were increased by $30 \%$ to allow for wastage, and labour rate was increased by $100 \%$ to account for extra work.

In order to achieve structural optimization, for each column, sectional area properties were varied for brickwork, reinforced brickwork, and reinforced concrete solutions respectively. The design study included a total of 39 column locations and $351(=39 \times 3 \times 3)$ brickwork, reinforced brickwork and reinforced concrete structurally optimized solutions to cover the three different foundation conditions considered. 


\section{Results and Analysis}

\subsection{From the Literature Survey}

Reinforced brickwork was found to be used locally for applications such as: tall brick columns, gate posts, parapet walls of balconies, door and window lintels, narrow brick columns, brick foundations susceptible to differential settlements, cyclone proof housing, and crack control of walls subject to movement.

Due to low strength of local mortar, small diameter reinforcements in mortar joints are not preferred due to durability problems, unless galvanized small diameter steel is used. A concrete core to surround the reinforcement in reinforced brickwork is preferred and it can be provided by cutting bricks as required. However, with local brickwork, the concrete core is often created by positioning bricks standing on narrow long sides or by using Quetta bond, which creates a central cavity for reinforcements in columns.

In reinforced masonry columns, surface area and number of reinforcements, rather than the cross-sectional area, were found to be important as the force that could be transferred to reinforcement through bond from weak masonry is a decisive factor.

Encasement of reinforcements in Grade 20 concrete with minimum $25 \mathrm{~mm}$ cover was considered adequate [12] owing to presence of surrounding brickwork, as columns of up to twostoreyed houses are subjected to E1 (internal work or similar) exposed condition of BS5628[3].

For concrete areas of small size in reinforced brickwork columns, nominal maximum aggregate size should be reduced from $20 \mathrm{~mm}$ to $14 \mathrm{~mm}$ such that: (a) nominal maximum aggregate size should be not greater than onequarter of the minimum dimension of the concrete pocket; (b) horizontal distance between two reinforcements should be not less than nominal maximum aggregates plus $5 \mathrm{~mm}$; (c) vertical distance between reinforcements, where applicable, should not be less than 2/3rd of nominal maximum aggregate size; and (d) concrete cover is not less than the nominal maximum aggregate size.

A suitable construction sequence for reinforced brickwiork columns [2] would be: (i) Create a concrete core with bricks standing on narrow long edge or using Quetta bond; (ii) Place the reinforcements starting from the pad fasting and hold them in position by external means such as coir rope anchors; (iii) Concrete the pad footing; (iv) Lay brickwork surrounding the reinforcements to about $450 \mathrm{~mm}$ height [3]; (v) After brickwork hardens (about 2. days) clean the concrete core boundaries from any dust by cleaning and washing to ensure good bond between concrete and brickwork face; (vi) Place concrete (Grade 20 with $14 \mathrm{~mm}$ aggregate) inside saturated but surface dry brickwork shell (to minimize water absorption from concrete mix) in lifts about $200 \mathrm{~mm}$, but not exceeding $200 \mathrm{~mm}$ or six times the width of the grout space, compacting well with a steel rod or poker vibrator (if space permits); (vii) Due to low strength of brickwork shell, low-lift concreting is preferred. A lift is a layer of concrete placed in a single operation. One or more lifts constitute a pour, which is the total height of concrete placed in brickwork shell before construction of additional brickwork. However, if a lift of concrete sets for more than about 1 hour before placement of the next lift, then that is the pour height. A pour should end at least $50 \mathrm{~mm}$ before a bed joint to form a shear key [3,5]; and (viii) When concrete hardens (about 24 hours) readjust supports of reinforcements and continue the process.

\subsection{From the Design Study}

\subsubsection{General}

SLS 39[15] brick size (mm) of 220 long $x 105$ wide $\times 65$ high, and compressive strength of $10.0,4.8$ and $2.8 \mathrm{~N} / \mathrm{mm}^{2}$ respectively, are not usually available. To cover most of the available brick types, non-standard brick size ( $\mathrm{mm}$ ) of 200 long $\times 95$ wide $\times 57$ high with a compressive strength of $2.0 \mathrm{~N} / \mathrm{mm}^{2}$ was adopted for the design study, so that results can be used for locally available bricks generally.

It was found that in brickwork walls of singlestorey sections of a house (or the upper-storey sections of a two-storey house), reinforced concrete or reinforced brickwork columns should be used instead of brickwork columns, if any of the following conditions exist: (a) load concentration ratio ( $=$ (tributary length from which load is transferred to the column) / (column width measured along the wall)) on a column, due to window or door opening on one 
side of the column only, is greater than 3.0; (b) load concentration ratio ( $=$ (tributary length from which load is transferred to the column) / (column width measured along the wall)) on a column, due to window or door opening on either side of the column, is greater than 5.0; and (c) wall length available for the column width is less than $450 \mathrm{~mm}$.

Thirty-nine column locations were considered in the study and the summary of the evaluated column loads are as follows: (a) Eccentricities varied from 3.23 to $37.50 \mathrm{~mm}$; (b) Ultimate loads varied from 5.648 to $50.530 \mathrm{kN}$; (c) Service loads varied from 4.701 to $34.848 \mathrm{kN}$; (d) Ultimate bending moments varied from 0.0847 to 1.1159 $\mathrm{kNm}$; and (e) Service bending moments varied from 0.0535 to $0.7696 \mathrm{kNm}$.

\subsubsection{For Good Soil $(200 \mathrm{kN} / \mathrm{m} 2$ Bearing Pressure)}

The recommended reinforced concrete column details are as follows: Column stem size (mm) 225x225; Main reinforcements 4Y12; Shear links R6 @ 125; Grade 20 concrete (1:2:4 (20mm)); Pad footing $(\mathrm{mm}) 500$ long $\times 500$ wide $\times 150$ thick; Cover in column $25 \mathrm{~mm}$; Cover in pad footing $40 \mathrm{~mm}$; Screed concrete of $75 \mathrm{~mm}$ thick Grade 15 mass concrete $(1: 3: 6(40 \mathrm{~mm}))$.

The recommended reinforced brickwork column details are as follows: Column stem size (mm) 305x305 (1.5 bricks wide); Brickwork in Quetta bond with bricks (mm) 200 long $\times 95$ wide $x 57$ high of compressive strength $2.0 \mathrm{~N} /$ $\mathrm{mm} 2$ in 1 cement: 5 sand mortar. Concrete core of size (mm) $115 \times 115$; Main reinforcement IR10 at column centre; No shear links; Grade 20 concrete $(1: 2: 4(20 \mathrm{~mm}))$ in column core and pad footing; pad footing ( $\mathrm{mm}$ ) 500 long $\times 500$ wide $x$ 100 thick; Cover in pad footing $40 \mathrm{~mm}$; Screed concrete of $75 \mathrm{~mm}$ thick Grade 15 mass concrete (1:3:6(40mm)).

The recommended unreinforced brickwork column details are as follows: Column stem size (mm) 410x410 (2 bricks wide); Brickwork in English bond with bricks (mm) 200 long $x 95$ wide $\times 57$ high of compressive strength $2.0 \mathrm{~N} /$ $\mathrm{mm} 2$ in 1 cement: 5 sand mortar; Pad footing (mm) $600 \times 600 \times 175$ thick in Grade 15 mass concrete (1:3:6 (40mm)).

In selection of a column type (see Figure 1), attention should be paid to the fact that the cheapest column is of reinforced brickwork, intermediate is of unreinforced brickwork and costliest is of reinforced concrete.

\subsubsection{For Average Soil $\left(125 \mathrm{kN} / \mathrm{m}^{2}\right.$ Bearing Pressure)}

The recommended reinforced concrete column details are as follows: Column stem details are as for good soil; Pad footing (mm) 600 long $\times 600$ wide $x 200$ thick. In the pad footing, cover was $40 \mathrm{~mm}$ and concrete was Grade 20 (1:2:4 $(20 \mathrm{~mm})$ ); Screed concrete was of $75 \mathrm{~mm}$ thick Grade 15 mass concrete (1:3:6 $(40 \mathrm{~mm}))$.

The recommended reinforced brickwork column details are as follows: Column stem details are as for good soil; pad footing (mm) 600 long $\times 600$ wide $\times 150$ thick; In the pad footing, cover was $40 \mathrm{~mm}$ and concrete was Grade 20 (1:2:4(20mm)); Screed concrete was of $75 \mathrm{~mm}$ thick Grade 15 mass concrete (1:3:6(40mm)).

The recommended unreinforced brickwork column details are as follows: Column stem details are as for good soil; pad footing $(\mathrm{mm}) 700$ long $\times 700$ wide $\times 225$ thick in Grade 15 mass concrete 1:3:6 $(40 \mathrm{~mm})$.

The cost, a useful guide in selection of a column type (see Figure 1), varies as in the last paragraph of 3.2.2.

\subsubsection{For Poor Soil ( $50 \mathrm{kN} / \mathrm{m}^{2}$ Bearing Pressure)}

The recommended reinforced concrete column details are as follows: Column stem details are as for good soil; Pad footing (mm) 850 long $\times 850$ wide $\mathrm{x} \mathbf{3 2 5}$ thick; In the pad footing, cover was $40 \mathrm{~mm}$ and concrete was of Grade 20 (1:2:4 $(20 \mathrm{~mm})$; Screed concrete was of $75 \mathrm{~mm}$ thick Grade 15 mass concrete (1:3:6(40 mm)).

The recommended reinforced brickwork column details are as follows: Column stem details are as for good soil; Pad footing (mm) $850 \log \times 800$ wide $x 275$ thick; In the pad footing, cover was $40 \mathrm{~mm}$ and concrete was of Grade 20 $(1: 2: 4(20 \mathrm{~mm}))$; Screed concrete was of $75 \mathrm{~mm}$ thick Grade 15 mass concrete (1:3:6(40mm)).

The recommended unreinforced brickwork column details are as follows: Column stem details are as for good soil; Pad footing (mm) 900 long $\times 900$ wide $\times 325$ thick in Grade 15 mass concrete 1:3:6 $(40 \mathrm{~mm})$. 




(a) Relnferced Conoto

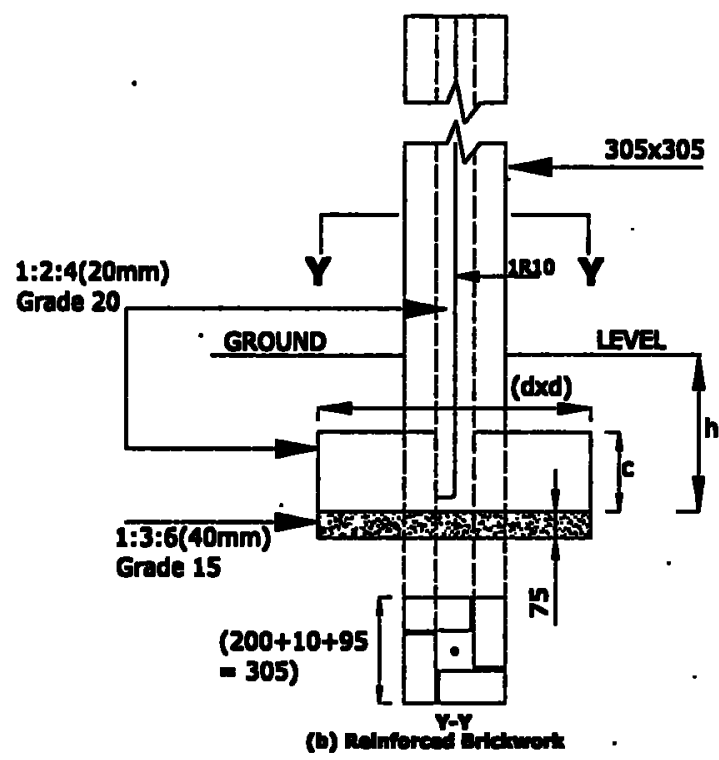

Figure1-Recommended Column Solutions

The cost, a useful guide in selection of a column type (see Figure 1), varies as in the last paragraph of 3.2.2.

\section{Conclusions:}

Following conclusions are made, on singlestorey columns of houses subject to roof and ceiling loads, from this study:

(a) Cost of a column increases from reinforced brickwork, unreinforced brickwork to reinforced concrete;

\section{NOTES}

1.All dimensions in $\mathrm{mm}$

2.a,b,c,d,e and $f$ values for good, average and poor soll, see 3.2.2, 3.2.3 and 3.2.4

$3 . \mathrm{h}(\mathrm{mm})$ for good, average and poor soll are 750,750 and 1000 .

4.Cover for reinforced concrete column and foundation pad are 25 and $\mathbf{4 0}$.

5.Figures are not to scale.

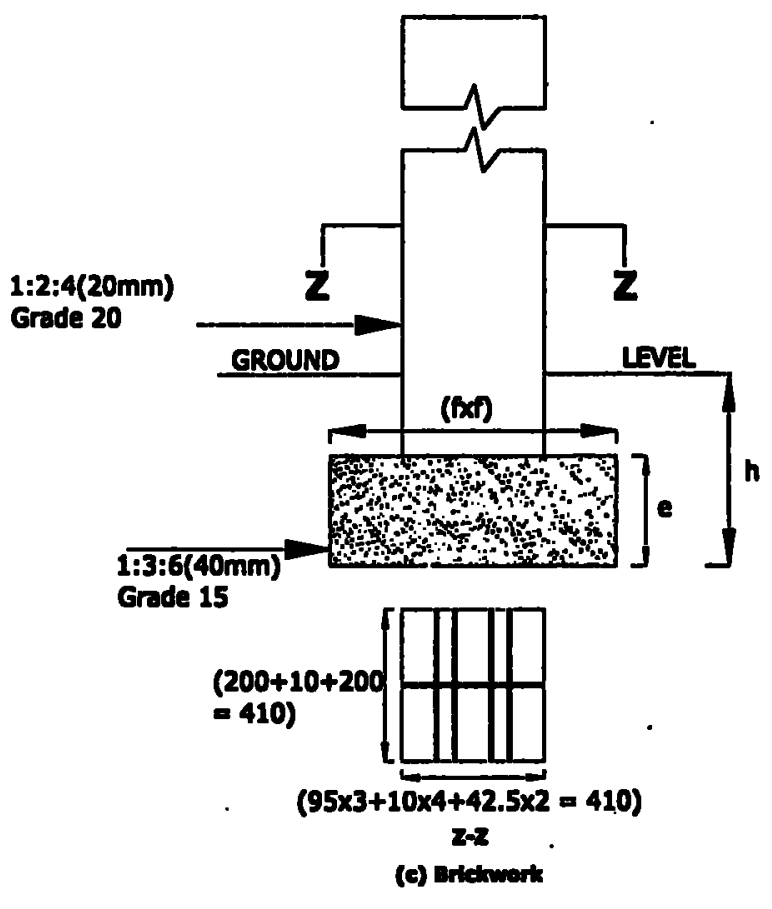

(b) Bulkier unreinforced brickwork columns are unlikely to be popular, unless for architectural reasons;

(c) A suitable column can be selected from 3.2, depending on soil conditions and cost preference (also see Figure 1);

(d) Reduction of the size of a reinforced concrete column below $225 \mathrm{~mm}$ changes it from a short to a slender column, making it uneconomical; 
(e) None of the recommended columns require a reinforced concrete pad footing, although pads of reinforced concrete columns and reinforced brickwork columns require Grade 20 concrete, while those of unreinforced brickwork columns require Grade 15 mass concrete; and

(f) Square columns are superior to rectangular columns due to reduction of cost possible from the pad foundation, when columns carry predominantly axial loads.

\section{References:}

1. BS 8110: Part 1, "Structural Use of Concrete Code of Practice for Design and Construction", British Standards Institution, 1985.

2. Rupasinghe, T.N., Weerasinghe, T., and Senarath, S.A.A.S., "Feasibility Study on the Use of Brickwork and Reinforced Brickwork Columns to Replace Reinforced Concrete Columns in up to Two-Storeyed Houses", Final Year Project Report, Department of Civil Engineering, University of Moratuwa, 2003.

3. BS 5628:Parts 1,2 and 3, "Code of Practice for Structural Use of Masonry", British Standards Institution, London 1992.

4. Schneider, R.R., and Dickey, W.L., "Reinforced Masonry Design", Prentice - Hall Inc., Englewood Cliffs, New Jersey, 1987.

5. Taly, N., "Design of Reinforced Masonry Structures", McGraw-Hill Company Inc., USA, 2001.

6. Hendry, A.W., Sinha, B.P., and Davies, S.R., "Design of Masonry Structures", E \& F.N. Spon Limited, London, 1980.

7. Roberts, J.J., Edgell, G.J., and Rathbone, A.J., "Handbook to BS 5628: Part 2", A Viewpoint Publication, London, 1986.

8. Curtin, W.G., Shaw, G., and Beck, J.K., "Design of Reinforced and Prestressed Masonry", Thames Telford Limited, London, 1988.

9. Amrhein, J.E., "Reinforced Masonry Engineering Handbook", Masonry Institute of America, 1973.

10. Chandrakeerthy, S.R.De S., Jayawardena, D.S., and Pannila, S.D., "Feasibility of Reinforced Brickwork Beams Using Low Strength High Water Absorption Bricks", Masonry International, (8), pp 1-7, July 1986.

11. Chandrakeerthy, S.R.De S., "Reinforced Brickwork Beams Using Low Strength High Water Absorption Bricks in Exposed Situations", Masonry International, 5(3), pp65-68, 1992.
12. Chandrakeerthy, S.R.De S., "Durability of Reinforcement in Brickwork Made with Local Materials", Transactions of the Institution of Engineers, Sri Lanka, 1, pp15-30, October 1989.

13. Perera, A.A.D.J., "Computerized Builders Schedule of Rates", University of Moratuwa. 2004.

14. BS 8000: Part 3, "Workmanship on Building Sites - Code of Practice for Masonry", British Standards Institution, 1989.

15. SLS 39, "Common Burnt Clay Building Bricks", Sri Lanka Standards Institution, 1978.

16. Chandrakeerthy, S.R.De S., and Wimalasena, B.D.S., "Brickwork Columns to Carry Upper Floor Loads of Two-storeyed Houses", Transactions of the Institution of Engineers, Sri Lanka, I(B), pp 21-29, October 2004.

17. Chandrakeerthy, S.R.De S., and Tharanganie, B.G.N., "Feasibility of Single-Storey Blockwork columns for House Construction ", Transactions of the Institution of Engineers, Sri Lanka, I (B), pp 13-20, October 2004.

18. Adams, S., "Brick Column Construction for Commercial buildings", Paper 2, pp 13-20, in Practical Design of Mnsonry Structures, Thames Telford Limited, London, 1986.

19. Bradshaw, R.E., "New Head Office for Accrington Brick and Tile Company Limited", Paper 10, pp 133-143, in Practical Design of Masonry Structures, Thames Telford Limited, London, 1986. 